\title{
Å tilrettelegge for at lektorstudenten lærer å lære fra seg i første semester
}

\author{
Amir Hashemi \\ Avdeling for ingeniør- og økonomifag, \\ Høgskulen på Vestlandet \\ Sigrun Eriksdotter Eggereide, \\ Integrert lektorutdanning, \\ Det Matematisk-naturvitenskapelige fakultetet, \\ Universitetet i Bergen
}

\begin{abstract}
ABSTRAKT: Vi ønsker å dele erfaringer fra en workshop som har blitt arrangert for lektorstudentene som går sitt første semester på lektorutdanningen ved UiB, og tar fordypning i realfag og matematikk. Vi vil i denne artikkelen undersøke hvordan en studentaktiv metode kan bidra til lærerstudentenes profesjonsutvikling. Den studentaktive metoden vi referer til er den workshopen vi har arrangert, og målet var at den skulle bidra til at studentene fikk ferdigheter til å reflektere over sin egen læringsprosess, og pedagogisk, faglig og fagdidaktisk trygghet. Ønsket var at studentene også fikk erfare mestring og få trening i å kommunisere med deres lærende. Disse elementene kan gi studentene gode erfaringer med lærerrollen før hoveddelen av lærerpraksisen, som kommer først på fjerde året.
\end{abstract}

Keywords: teaching education, student active learning

\section{BAKGRUNN}

Det står i nasjonale retningslinjer for lektorutdanningen for 8-13 trinn (UHR, 2015) at «Lærerutdanninger skal være profesjonsrettede og integrerte, praksisnære og relevante, forskningsbaserte og utviklingsorienterte, krevende og ha høy kvalitet». Det står også at «Utdanningene skal bidra til at studentene opparbeider en kritisk og reflektert holdning til egen praksis og kan arbeide med endrings- og utviklingsarbeid i egen organisasjon».

Mange vil si at det viktigste med å være lærer handler om å formidle sitt fag til de lærende på en god måte. En stor del av denne formidlingen er å kunne forklare det faglige på mange ulike, men like gode måter. For å få til dette kreves det en dyp og grundig forståelse av faget, som når langt ut over det som skal formidles.

I den femårige lektorutdanningen på Universitetet i Bergen har studentene fordypningen i sine fag separat fra pedagogikk og didaktikk. En kan da stille spørsmålet om når i lektorutdanningen ved universitetet de fremtidige lærerne skal tilegne seg denne kunnskapen om hvordan man best forklarer fag. Lærer de dette ved å høre på sine forelesere i matematikk, kjemi, fysikk eller biologi? Lærer de det i pedagogikken eller i didaktikken? Mange lektorstudenter mener at denne typen kunnskap er noe som må opparbeides ved erfaring, prøving og feiling, og da særlig i undervisningspraksisen. Men det er først på fjerde året studentene får komme ut i praksis og ha hovedansvaret for undervisningen.

Didaktikkworkshopen har dermed vært et forsøk på å sette i gang denne prosessen med å tilegne seg disse ferdighetene allerede første semester på lektorstudiet. 
Praksisen i lektorutdanningen ved UiB har vært mye diskutert det siste året. I denne debatten fremmer studentene at de ønsker å kunne dedikere seg fullt og helt til praksisen, men ikke får muligheten til dette slik studiet er lagt opp. Det er i praksisen man får brukt og knyttet sammen alle de teoretiske kunnskapene man har tilegnet seg på universitetet (Eggereide, S., 2016). I denne debatten i studentavisen Studvest kommer det frem hvor opptatte lektorstudentene er av kvalitet i praksisen sin. Fagutvalget for integrert lektorutdanning (FIL) opplever også at mange studenter hadde ønsket at praksisen kom tidligere i studieløpet. Slik utdanningsløpet er lagt opp nå ved UiB har studentene 7 dager praksis hver høst de første tre årene, og på fjerde året har de 49 dager i høstsemesteret og 30 dager i vårsemesteret (Studieplan, 2016). De første tre årene er hovedfokuset på observasjon (Emnebeskrivelse 2017b, 2017c, 2017d), og det er først på fjerde året at studentene får hovedansvaret for undervisningen i en klasse (Emnebeskrivelse, 2017a). Dette er en av grunnene til at vi mener at workshopen kan være viktig for studentene. Det tar lang tid før de virkelig får prøvd seg på å undervise, og ved hjelp av denne arbeidsmetoden får de prøvd litt tidligere. I workshopen får de forberedt seg på hvordan det er å forklare matematikk for andre studenter, og får dermed forberedt seg på lærerrollen og den praksisen de skal ha senere i studieløpet.

\section{PROBLEMSTILLING OG METODE}

Vår problemstilling er "Hvordan kan en studentaktiv metode tidlig i studiet bidra til lærerstudentenes profesjonsutvikling?" Vi bruker erfaringene til de studentene som har deltatt i workshopen til å studere hvilken rolle workshopen har spilt for dem. Her ønsker vi å undersøke om studentene føler det har påvirket deres selvtillit som lærer, læringsprosesser i de videre studiene og opplevelse av fremgang i praksisen senere i studiet. I dette arbeidet har vi benyttet en kvalitativ didaktisk forskningsmetode. Det empiriske materialet er basert på samtaler med studentene som deltok i workshopen og feedback på e-post i løpet av studiene om hvordan workshopen har påvirket deres læring og praksis. Noen av studentenes tilbakemeldinger er inkludert i artikkelen.

\section{REDEGJØRELSE OG DRØFTING}

I oppgaveregningstimene i MAT101 (Brukerkurs i matematikk) høsten 2012 oppdaget MAT101-foreleseren (Amir Hashemi) at lektorstudentene hadde lite trening i muntlig formidlingsevne og arrangerte en workshop for de interesserte høsten 2013. Senere var det FIL som tok over arrangementet og MAT101-foreleseren ble da invitert til å være mentor i workshopen. Like etter semesterstart har FIL sendt ut informasjon til lektorstudentene om at de får tilbud om å delta på denne matematikkdidaktikk-workshopen, og at det er plass til åtte studenter. Workshopen er ikke en obligatorisk del av utdanningen, og er altså frivillig for studentene å delta på. Workshopen har bestått av seks samlinger der mentoren har presentert et emne og bedt studentene reflektere over detaljene i dette emnet. Lektorstudentene har fătt utdelt oppsummeringsnotater og oppgaver med fasit som senere skal regnes på tavla. De får tid til å tenke litt individuelt, og deretter gjøre en utregning på tavla hvor de fortløpende får tilbakemeldinger fra mentor og sine medstudenter.

Fordelen med et slikt undervisningsopplegg i det første semesteret til lektorstudentene er at det kan dreie studentenes fokus mot å lære faget for å undervise i det, i tillegg til at de blir vant til å ha rollen som underviser. Disse erfaringene kan de ta med seg videre i studiene. Vi mener at en slik type workshop hvor lærerstudentene får prøvd seg på underviserrollen er viktig av ulike grunner. Studentene får mulighet til å reflektere over sine egne læringsprosesser og kan få tilbakemeldinger fra sine medstudenter i et trygt læringsmiljø. De får mulighet til å oppleve mestringsfølelse ved å få til det å undervise, som kan føre til bedre selvtillit, som er en viktig faktor for læring (Norman, Marie and Hyland, Terry, 2003). De blir 
også vant til å kommunisere med sine elever, og venner seg til å få og forholde seg til konstruktive tilbakemeldinger. Dette kan forberede dem på den prosessen de senere skal inn i når praksisperiodene begynner, som går ut på å analysere sin egen undervisning og være kritisk reflekterende ovenfor sin egen praksis (Emnebeskrivelse, 2017a).

Workshopen ble arrangert for første gang høsten 2013. MAT101-foreleseren spurte midt i semesteret i forelesningstimen en av deltakerne på workshopen om å komme og regne en oppgave på tavlen, noe som studenten gjorde og forklarte matematikken underveis. På denne forelesningen var det ca 200 studenter tilstede, og for forfatterne var dette en indikasjon på at workshopen hadde den effekten vi ønsket - nemlig at studentene har tilegnet seg både formidlingsferdigheter og selvfølelse.

Medforfatter til denne artikkelen (Sigrun Eggereide) var en av de første som tok kurset og mener at tiltaket bidro til betydelig fremgang både i hennes skriftlige og muntlige formidlingsevner i matematikk. Hashemi (2016) beskriver viktigheten av å tilrettelegge "problembasert og studentaktiv læringsmetode" for at studentene kan formulere og uttrykke seg, og snakke matematikk i timene og øvingstimene som kan bidra til å aktivisere minne og dermed lære emnet mer effektiv og huske bedre.

Det var flere faktorer som gjorde at forfatterne av artikkelen fikk et ønske om å undersøke studentenes oppfatning av workshopen. For det første hadde flere studenter uttrykt både underveis i workshopen og i etterkant, at det var noe som opplevdes som nyttig for dem. For det andre var praksis i lektorutdanningen et tema som ble diskutert i studentavisen Studvest våren 2016 (Eggereide, 2016). Det ble særlig poengtert at det er en mangel på kontinuitet i praksisen til lektorstudenene. I og med at workshopen er en praksisnær aktivitet, ønsket vi å undersøke nærmere hva studentene syns de hadde fått ut av workshopen. Vi fikk tilbakemeldinger fra 10 studenter, og stilte dem følgende spørsmål:

- I hvilken grad har workshopen hjulpet deg med å bli kjent med dine formidlingsevner og eventuelt forbedret dem?

- Var det nyttig å ha workshopen i det første semesteret?

Det er ca. 20 studenter som har deltatt aktivt i workshopen siden tiltaket startet i 2013. Det var mulig få tak i 10 av disse, og datamaterialet er basert på svarene vi har fått fra de som har svart spørsmålene. Datamaterialet er dermed ikke så stort, og kandidatene som svarte på spørsmålene har svart mellom 2-4 år etter at de tok workshopen og er dermed svarene basert på deres erfaringer over tid. Svarene er også relatert til deres fremgang i studiet og praksisperioden.

Mange knytter erfaringene i workshopen sammen med senere erfaringer i studietiden, og flere forteller om at workshopen har bidratt mye til deres egen læringsprosess. Studentene beskriver at workshopen bidro til at de ble mer komfortable med å stå foran tavla, fikk god øvelse i formidle. Mange nevnte også at det var veldig nyttig å få tilbakemeldinger fra sine medstudenter, og de syns alt $i$ alt at workshopen var lærerik. Oppsummering av noen av tilbakemeldingene kan leses i (Tilbakemeldinger 2016).

Det er tydelig at lektorstudentene er klar over at det kreves mer av dem enn at de skal være reflektert over sine egne læringsprosesser. De studerer ikke bare for å lære selv, men for å lære å formidle det de kan til andre. En stor del av denne formidlingen er å kunne forklare det faglige på mange ulike, men like gode måter. For å få til dette kreves det en dyp og grundig 
forståelse av faget, som går langt ut over det som skal formidles (Ingvarson, Beavis \& Kleinhenz, 2007). Vi mener at jo tidligere lektorstudentene får prøve seg på lærerrollen, jo mer sannsynlig er det at de tidlig begynner å reflektere over sin formidlingskompetanse. Dette blir støttet av ulik litteratur, som vi kommer videre inn på i artikkelen.

Ferdigheter og kunnskap som en skal lære seg må praktiseres gjentatte ganger i stadig mer komplekse sammenhenger for at lærerkandidaten skal lære. Derfor bør lektorstudentene ha en praksisbasert utdanning for å få muligheten til refleksjon og tilbakemeldinger. Slike erfaringer hjelper studentene å bli uavhengige (Beed, Hawkins \& Roller, 1991). Ball og Cohen (1999) beskriver også viktigheten av en profesjonsbasert lærerutdanning, men påpeker at praksisen ikke nødvendigvis alltid trenger å være nøyaktig slik det kommer til å være i det fremtidige yrket til studentene. Det viktige er at man definerer de sentrale aktivitetene i lærerprofesjonen og at man velger ut materiale å arbeide med som skaper en riktig fremstilling av yrket, men likevel kan tilpasses til studentens nivå (Ball \& Cohen, 1999). Vi mener at workshopen er bygget opp rundt disse prinsippene. Undervisning er utvilsom en sentral aktivitet $i$ lærerprofesjonen, og studentene får mulighet til å øve seg på den situasjonen. Nivået er tilpasset deres aktuelle ferdighetsnivå, ved at faget som de arbeider med er et fag de følger samme semester.

Darling-Hammond (2006) beskriver tre utfordringer som en nyutdannet lærer må takle. Den første utfordringen er at den nyutdannede må begynne å se på undervisning på en annen måte, hvor egne erfaringer som elev eller student må adskilles fra den nye kunnskapen om å undervise. Den andre utfordringen er at den nyutdannede både må lære seg å tenke som en lærer, men også oppføre seg som en lærer. Den tredje utfordringen innebærer at de må kunne tilpasse den komplekse undervisningssituasjonen til det aktuelle klasserommet og den aktuelle situasjon, som kan endres på et øyeblikk. Hun trekker deretter frem mange trekk ved de lærerutdanningene som forbereder lærerstudentene godt på det som venter. Et av disse trekkene er at studentene får en veiledet lærerpraksis hvor aktivitetene er velvalgte og tett vevet sammen med fagstoffet som lærerstudentene skal lære (Darling-Hammond, 2006). En kan tenke seg at en slik workshop som beskrives i denne artikkelen kan være en god måte å veve praksis sammen med fagstoffet, og dermed forberede lærerstudentene på de utfordringene som møter dem i skolen. Harwell (2003) påpeker at den profesjonelle utviklingen til en lærerstudent eller lærer ikke er skjer i en isolert hendelse, men er en prosess. Målet med workshopen er å bidra til denne prosessen som er studentens profesjonelle utvikling. I en av tilbakemeldingene kommer frem:

\section{Jeg ble mer reflektert over egen lceringsprosess, både i matematikkfaget jeg presenterte, og $i$} rollen som loerer og underviser.

Assosiasjonistiske, kognitive og situative perspektiver er sentrale begreper i læringsteorier. Ved å bruke de situative brillene vil vi undersøke læringen til lærerstudentene i ulike situasjoner. Disse situasjonene inkluderer universitetets kurs i naturvitenskapene og matematikk, pedagogikk og fagdidaktikk, skolens praksisfelt (praksisperioden), og forberedende erfaringer (workshop og refleksjon i grupper). For å forstå en lærerstudents læring - i følge det situative perspektivet - må en studere læringen i disse ulike situasjonene, og ta hensyn til både de enkelte lærer-elev-forholdene og de fysiske og sosiale systemene der studentene er deltakere (Putnam og Borko, 2000). På lignende måte beskriver Cohen og kolleger lærerpraksisen som en samhandling og en interaksjon mellom lærerstudentene, lærerutdannere, innholdet i utdanningen (det som skal læres) og omgivelsene (Cohen, Raudenbush \& Ball, 2003). Det er dermed viktig å se det helhetlige bildet av en lærerstudents 
studiehverdag. Studentaktive metoder som workshopen vi har arrangert kan være en slik aktivitet som knytter fagstoffet tettere sammen med didaktikken, og dermed tilrettelegger for et godt samspill mellom de ulike delene av lærerutdanningen. I en av tilbakemeldingene ble nevnt:

På workshopen fikk vi med en gang fokusert på hvordan vi kan forklare og lore bort den matematikken vi også prøvde å loere oss selv.

Ingvarson, Beavis \& Kleinhenz (2007) har studert hva som karakteriserer en effektiv lærerutdanning, altså hva som gjør at lærerutdanningen forbereder studentene for deres fremtidige yrke. De fant blant annet at det er essensielt med en praksiserfaring hvor det er muligheter for å få tilbakemelding på sin undervisning. De påpeker at dette lenge er blitt ansett som vitalt for at lærerstudenten skal kunne utvikle nye ferdigheter og implementere disse i undervisningen. Lærerutdanning er en profesjonsbasert utdanning, og praksisen må tilrettelegges slik at lærerkandidatene kan utvikle seg og praktisere deres faglige, didaktiske og pedagogiske kunnskap (Ingvarson, Beavis \& Kleinhenz, 2007). Workshopen som er blitt arrangert på UiB tilrettelegger for en mulighet for å få tilbakemelding på undervisning. Denne muligheten er i utgangspunktet svært begrenset de første årene av utdanningen, da praksisperiodene er på maksimalt syv dager i året, de første tre årene (Studieplan, 2016). På denne måten kan workshopen bidra til å tidligere begynne å forberede studentene på den viktige delen av læreryrket som består av å hele tiden forbedre sin undervisning.

Lærerstudentene trenger muligheter til å prøve ut sine idéer i praksis og kunnskap om og støtte til å reflektere over og tolke praksis (Darling-Hammond, 1998). Schön (1983, 1987a, 1987b) påpeker at lærerstudentenes teoretiske kunnskaper og innsikt kan spille en rolle i studentenes adferd $\mathrm{i}$ undervisningen, men at dette ikke er avgjørende for undervisningens kvalitet. De reflekterende praksisene som innebærer å vurdere sin undervisning, ikke bare i forkant og etterkant av undervisningen, men også mens undervisningen pågår, er det som er avgjørende for undervisningens kvalitet. Dette omtales som "refleksjon under handling". Adler (2000) beskriver lærerutdanning som en prosess der kandidaten blir mer kunnskapsrik ved å praktisere undervisning, og øker dermed sin kompetanse ved å utøve læreryrket i praksis.

En lærerstudent går gjennom en prosess i lektorutdanningen for å bli en reflekterende didaktiker som kan se kritisk på sine undervisingsferdigheter og prøver å forbedre sine metoder. Tilbakemeldingene (spørre undersøkelse og samtale) fra deltagere tyder på at denne prosessen begynte tidlig i første semesteret i et trygt læringsmiljø der medstudenter kunne gi deres tilbakemeldinger bidro til at de bygget opp sin selvtillit og lærte å reflektere over sin praksis.

\section{OPPSUMMERING}

Det er godt dokumentert av forskning at praksis i lærerutdanningen er svært viktig (Ball \& Cohen, 1999; Adler, 2000; Darling-Hammond, L., 1998, 2006; Schön, 1983, 1987a, 1987b; Harwell, 2003). I tilbakemeldingene og samtalene ble dokumentert at workshopen har bidratt til at deltagere:

- Klarte å vende blikket ut fra sin egen forståelse og legge merke til hva de andre ikke forstod

- fikk trening i å utforske å formidle

- ble mer komfortabel å stå foran tavla 
- fikk bedre selvtillit for å stå foran tavla og formidle

- fikk hjalp til å venne seg til lærerrollen sin, som en som skal formidle og kunne svare på alle spørsmål

- opplevde at mange av temaene som ble gjennomgått gikk fra å virke uoverkommelige til å bli enkle

- lærte mye av å få tilbakemelding fra sine medelever

- lærte å reflektere over sin praksis

Erfaringene vi har gjort oss og tilbakemeldingene vi har fått indikerer at det er nødvendig å ha praksis i lektorstudiene på et tidligere tidspunkt enn det gis i dag på UiB. En slik workshop som vi har beskrevet, der studentene er med å observere, gi tilbakemeldinger til medstudenter, er med å presentere og få tilbakemeldinger, kan hjelpe studentene med å utvikle sine didaktiske, pedagogiske og faglige ferdigheter. Det å få mulighet til refleksjon, gi og få tilbakemeldinger kan gi lærerstudentene trening i å analysere sin undervisning og undervise effektivt, og legge grunnlaget for å fortsette med refleksjonene i de videre studiene og i yrket som lærer.

Vi mener derfor at et slikt undervisningsopplegg kan føre til positive effekter for en lærerstudents profesjonsutvikling.

\section{$5 \quad$ Forslag til mulig fremtidig arbeid}

Vi håper at erfaringene fra denne workshopen kan inspirere institusjoner som tilbyr lektorutdanning til å integrere et lignende tiltak som en obligatorisk del av lektorprogrammet. Tiltaket kan utvides og etableres for alle studieprogram (realfag, språk, samfunnsfag, ...). Forelesere kan inviteres til å være mentorer for slike workshoper, og de kan inspirere studentene med sine didaktiske og pedagogiske ferdigheter. Hensikten med tiltaket må være å gi lektorstudentene en mulighet til å tidlig få prøve å undervise, og å samtidig reflektere over sin egen undervisning. En svært viktig faktor er at dette skjer i et trygt undervisningsmiljø hvor man får tilbakemeldinger fra medelever på en konstruktiv måte. Vi mener at slike tilbakemeldinger kan føre til gode refleksjoner over egen undervisning, og dermed sette fart $\mathrm{i}$ studentenes læringsprosesser.

Avslutningsvis vil vi takke FIL og Marianne Jensen ved matematisk institutt (UiB) for å ha tilrettelagt matematikk didaktikk workshopen.

\section{REFERANSER}

Adler,J . (2000). Social practice theory and mathematics teacher education: A conversation between theory and practice. Nordic Mathematics Education Journal 8 (3), s. 31-53.

Ball, D. L. \& Cohen, D. K. (1999). Developing practice, developing practitioners: Toward a practicebased theory of professional education. In G. Sykes and L. Darling-Hammond (Eds.), Teaching as the learning profession: Handbook of policy and practice. San Francisco: Jossey Bass (s. 3-32).

Beed, P. L., Hawkins, E. M., \& Roller, C. M. (1991). Moving learners toward independence: The power of scaffolded instruction. The Reading Teacher, 44(9), s. 648-655.

Cohen, D. K., Raudenbush, S. W., \& Ball, D. L. (2003). Resources, instruction, and research. Educational Evaluation and Policy Analysis, 25, s. 119-142.

Darling-Hammond, L. (1998). Teachers and teaching: Testing policy hypotheses from a national commission report. Educational Researcher, 27 (1), s. 5-15. 
Darling-Hammond, L. (2006). Constructing 21st-century teacher education. Journal of Teacher Education, 57(3), s. 300-314.

Eggereide, S. (2016). UiBs dyktige lektorer med hjertet i praksis. Studvest. Hentet fra http://old3.studvest.no/uibs-dyktige-lektorer-med-hjertet-i-praksis/

Emnebeskrivelse ILPRA101. For MAMN-LÆRE Lektorprogram i naturvitenskap og matematikk (vår 2017). Hentet fra http://www.uib.no/emne/ILPRA101

Emnebeskrivelse KOPRA101. For MAMN-LÆRE Lektorprogram i naturvitenskap og matematikk (vår 2017). Hentet fra http://www.uib.no/emne/KOPRA101

Emnebeskrivelse KOPRA102. For MAMN-LÆRE Lektorprogram i naturvitenskap og matematikk (vår 2017). Hentet fra http://www.uib.no/emne/KOPRA102

Emnebeskrivelse KOPRA103. For MAMN-LÆRE Lektorprogram i naturvitenskap og matematikk (vår 2017). Hentet fra http://www.uib.no/emne/KOPRA103

Harwell, S. H. (2003). Teacher professional development: It's not an event, it's a process. Waco, TX: CORD. Retrieved January, 21, 2004.

Hashemi A. (2016), Promoting a Culture of Learning through Talking to Understand Mathematics, presented at European First Year Experience (EFYE) 2016, Ghent, Belgium.

Ingvarson, L., Beavis, A., \& Kleinhenz, E. (2007). Factors affecting the impact of teacher education programs on teacher preparedness: Implications for accreditation policy. European Journal of Teacher Education, 30(4), s. 351-381.

Nasjonale retningslinjer for lektorutdanning trinn 8-13. Hentet fra http://www.uhr.no/documents/Nasjonale_retningslinjer_LU_8_13.pdf

Studieplan for MAMN-LÆRE Lektorprogram i naturvitenskap og matematikk (haust 2016). Hentet fra http://www.uib.no/studieprogram/MAMN-L\%c3\%86RE/plan

Norman, M. and Hyland, T.(2003). The role of confidence in lifelong learning. Educational Studies 29 (2-3), 261-272.

Putnam, R., \& Borko, H. (2000). What do new views of knowledge and thinking have to say about research on teacher learning? Educational Researcher 2, 9(1), s. 4-15.

Schön, D. A.(1983). The reflective practitioner: how professionals thinking action. New York: Basic Books.

Schön, D. A. (1987a). Educating the reflective practitioner. Washington, DC.: American Educational Research Association.

Schön, D. A. (1987b). Educating the reflective practitioner. San Francisco: Jossey-Bass.

Tilbakemeldinger fra workshopen (2016). Hentet fra http:/home.hib.no/ansatte/ahas/fil/tilbakemeldinger-workshop.pdf

UHR (2015). Forskrifter med merknader og gjeldende retningslinjer, for lærerutdanningene. 